\title{
ГУМАНІТАРНИЙ АСПЕКТ ПІДГОТОВКИ ЛІКАРІВ У ВИЩИХ МЕДИЧНИХ ЗАКЛАДАХ ОСВІТИ
}

\author{
Н. В. Скрипник, Н. В. Пассчко* \\ ДВНЗ “Івано-Франківський національний медичний університет”, \\ *ДВНЗ “Тернопільський державний медичний університет імені І. Я. Горбачевського МОЗ Украйни”
}

\section{HUMANITARIEN ASPECT OF TRAINING OF PHYSICIANS IN HIGHER MEDICAL EDUCATION INSTITUTIONS}

\author{
N. V. Skrypnyk, N. V. Pasyechko* \\ SHEI "Ivano-Frankivsk National Medical University", \\ *SHEI "Ternopil State Medical University by I. Ya. Horbachevsky of MPH of Ukraine”
}

\begin{abstract}
У статті йдеться про актуальні проблеми сучасної професійної підготовки майбутніх лікарів. При цьому окреслюються головні шляхи формування спеціаліста нової формації, обгрунтовується єдина цілісність процесів навчання і виховання, формулюються основні виховні аспекти.
\end{abstract}

The issues of doctors' modern professional training are considered in the article. The main ways of forming a new generation specialist are defined. The unity of teaching and educational processes is proved. The basic educational aspects are stated.

Вступ. Сучасний етап професійної медичної підготовки характеризується особливо зростаючою роллю педагогічної майстерності професорсько-викладацького складу, рівнем його психолого-педагогічної і методичної готовності управляти процесом підготовки висококваліфікованих спеціалістів у відповідності з сучасним рівнем вимог, щоб успішно вирішувати нагальні проблеми вищої медичної освіти [1].

Однією із важливих проблем цього процесу є невід'ємна складова, в ролі якої виступає гуманізація будь-якої освіти, а, тим більше, медичної - підготовки майбутніх поколінь лікарів. При цьому слід підкреслити, що саме гуманізація освіти на початку XXI століття є стратегічним напрямком перетворень усього інституту освіти. Адже концепція формування національної еліти, “особистості професіонала нової формації” [6], стає однією з ефективних інноваційних педагогічних технологій, що особливо актуально у період входження України до єдиного європейського освітнього простору.

Метою даної статті $є$ описати шляхи формування особистості професіонала нової формаціїу своїй галузі, обгрунтувати єдину цілісність процесів навчання і виховання, сформулювати основні виховні аспекти та спробувати визначити головні комунікативні установки.

Тому професійна підготовка медичного працівника ставить за мету формування не лише системи ( ) Н. В. Скрипник, Н. В. Пасєчко знань, вмінь, навичок, але й розвиток специфічних рис особистості, що відповідають вимогам майбутньої професійної діяльності. Іншими словами: ідеться про формування цілісної особистості, яка має не лише професійне спрямування й передбачає і залучення iï до системи загальнолюдських, гуманістичних цінностей [5]. Тобто мова йде про цілісність формування кваліфікованого фахівця, збагаченого й сформованого духовно. Адже ж це умови ХХІ століття, коли “зростає рівень інтелектуального, морально-етичного, естетичного та емоційного розвитку суспільства в цілому і окремого індивіда, його душі, сумління, свідомості, інтуїцію' [3]. А це говорить про те, що процеси навчання та виховання не можна в ніякому разі відокремлювати. Вони нерозривно пов'язані, саме тому, що перший, висуваючи все складніші завдання перед студентом і занурюючи його у реальний простір професійної діяльності, спричиняс активне залучення у розвиток психологічних процесів та певних якостей особистості. Тому залежно від змісту, форми, методів, складності, спрямованості, характеру процесу навчання отримуємо той чи інший результат у плані розвитку особистості стосовно її відповідності до сучасних вимог професії та суспільства.

Основна частина. Процес навчання у медичному навчальному закладі при умовах ефективної його організації сприяє професійно-орієнтованому розвит- 
ку процесів майбутнього медичного працівника, специфічних суто медичних: сприймання та пам'яті (зорових, слухових, тактильних, сенсорних та ін.), клінічного мислення та уяви, професійної уваги і т. д. Крім того, успішно побудований процес навчання об' єктивно стимулює розвиток системи професійнозначимих рис особистості, таких як: відповідальність, комунікабельність, стриманість, толерантність, емпатійність, витривалість та мобільність стосовно екстремальних професійних ситуацій. При цьому слід наголосити, що розвиток особистості в цілому та їі професійної підструктури в юнацькому віці є складним процесом. Він передбачає проникнення у їі ціннісні, установочні, морально-етичні, мотиваційні структури, що є стрижневими, глибинними рисами, достатньо стійкими, замаскованими, захищеними і тими, що рідко проявляються безпосередньо [2].

Виходячи з мети даної статті, зупинимось коротко на психологічних умовах розвитку професійної підструктури особистості медпрацівника, що вимагає від викладача вищого закладу освіти майстерного володіння психологічним інструментарієм впливу.

У цьому зв'язку, слід акцентувати увагу, що однією з головних психологічних умов $є$ органічна єдність виховного матеріалу із змістом теми, що вивчається. Ніякого штучного нав' язування, голого декларування абстрактних ідей тут не повинно бути. Виховна інформація, обумовлена темою, повинна природно й органічно випливати із їі змісту, психологічно-доступно сприйматися в єдності. У такому випадку вплив на глибинні структури особистості відбувається скоріше через канали підсвідомості, ніж свідомості. Неусвідомлення цього впливу є важливою умовою його ефективності.

Суттєвим психологічним моментом є також емоційне забарвлення виховної інформації. 3 цією метою може бути використаний будь-який матеріал, що викликає у студентів позитивні чи негативні емоції, сприяє виходу їх із стану емоційної рівноваги. Адже відомо, що найефективнішим є виховання через емоції та здивування.

На відміну від традиційного підходу до виховання виключно на позитивному прикладі сучасний підхід більше зорієнтований на використання широкої палітри інформації, ще об'єктивно відображає сучасний стан справ і проблем у системі охорони здоров'я та суспільства в цілому. Це сприяє створенню винятково важливої атмосфери довіри між викладачем та студентом, розвиває у студентів готовність до професійної діяльності в реальних умовах, дозволяє стимулювати їх до спільного пошуку шляхів вирішення проблем вітчизняної системи охорони здоров'я та суспільства.

Найактуальнішими в сучасному контексті можуть бути визнані такі виховні аспекти, як: деонтологічний, екологічний, правовий, професійної відповідальності, гуманістичний, патріотичний, психотерапевтичний, соціально-економічний тощо [4].

Залежно від теми, іiі змісту, значення в майбутній професійній діяльності, виховні цілі певної особи можуть бути сформульовані досить різноманітно, наприклад:

- розвинути деонтологічне уявлення, вміти здійснювати деонтологічний підхід до хворих $з$ певною патологією;

- розвинути уявлення про вплив екологічних, соціально-економічних факторів на стан здоров' я;

- розвинути уявлення про пріоритет вітчизняної медичної школи при вирішенні проблем... (на прикладі життя та діяльності видатних вчених-медиків, їх шкіл тощо);

- на матеріалі теми... розвинути почуття відповідальності за своєчасність і правильність професійних дій...;

- розвинути уявлення (навички) стосовно терапевтичного підходу до хворих певного профілю, їх родичів;

- сформувати систему сучасних правових понять, норм у контексті теми...;

- оволодіти вміннями встановлювати психологічний контакт 3 хворими і його родиною.

На основі викладеного вище, слід підкреслити, що в цілому сучасний виховний процес у вищих закладах освіти об'єктивно розвивається у бік гуманітарної орієнтації, побудованої на принципах гуманізму, розроблених і перевірених багатовіковою практикою. Адже сам термін “гуманітарний” означає “те, що робить своїм предметом людину”. Ідея і практика гуманізації суспільства та освіти передбачає визначення особистості - єдиної, унікальної, неповторної, індивідуальної, індивідуальності кожної людини, іiі життя і здоров' я, як пріоритетної домінуючої соціальної цінності, як найціннішого скарбу суспільства, збереження і розвитку якого потребує відповідальних умов.

Іншими словами, сам термін “гуманізм” означає передусім людяність людини: високий рівень психологічної терпимості (толерантності), любов до людей, м'якість в людських стосунках, повагу до особистості та їі достоїнства. Поняття “гуманізм” тлумачиться як система ціннісних орієнтацій, в центрі яких лежить визначення людини як найвищої цінності. 
Тому, виходячи з цього, гуманізація освіти передбачає декілька напрямків розвитку іiї технологій, що дозволяють:

- створити умови для максимального самоусвідомлення, саморозвитку, самореалізації особистості, розкриття закладених в ній потенцій, задатків, здібностей у відповідності до їі власної спрямованості та вибору;

- розширити гуманітарне ядро освіти з метою залучення майбутніх фахівців до системи загальнолюдських цінностей через занурення у різнобарвний ціннісний простір гуманітарних дисциплін, що акумулюють систему світових надбань 3 філософії, історії, культури, психології, педагогіки, соціології, права тощо.

Висновки. Підсумовуючи викладене вище, наголосимо, що серед проблем, над якими слід сьогодні наполегливо працювати в гуманітарному аспекті, це: вдосконалення структури та змісту гуманітарної підготовки майбутніх спеціалістів, органічне поєднан-

\section{Лiтература}

1. Грубінко В. В. Положення про організацію навчального процесу в кредитно-модульній системі підготовки фахівців / В. В. Грубінко, І. І. Бабин, О. В. Гузар. - Тернопіль : Вид-во ТНПУ ім. В. Гнатюка, 2004. -48 с.

2. Губаш О. П. Особливості управління навчальною діяльністю у системі дистанційного навчання / О. П. Губаш, В. В. Лапінський // Нові технології навчання : наук.-метод. зб. Спец. випуск/ кол. авт. -К. : Ін-тінноваційних технологій ізмісту освіти, 2006. -152 с.

3. Дичковський С. І. Неперервна гуманітарна освіта новий етап педагогічного мислення / С. І. Дичковський // Гуманітарні науки. -2004. -№ 2. - С. 29. ня усієї науково-педагогічної діяльності з історією, етнопедагогікою, культурою та традиціями України, пошук та оформлення ефективної моделі взаємовідносин викладача та студента, підвищення ефективності вивчення іноземних мов, зокрема, формування механізму управління гуманітарними процесами у вищих закладах освіти, взагалі, тощо.

Однією з найважливіших проблем вищої школи будь-якого профілю сьогодні повинно бути відродження іiї національної самобутності, бо саме вона покликана формувати майбутнє нації, ії соціальний та культурний генофонд. Адже ж відомо, що інтелектуальний рівень народу - це передусім похідна від рівня освіти. Тому, як вирішення цієї проблеми, повинно бути створена цілісна, обміркована й ефективна система, яка має взяти на себе функції підготовки не лише висококваліфікованих спеціалістів, але й (що найголовніше!) виховання людини, національно свідомої особистості, патріота України.

4. Мілерян В. С. Методичні основи підготовки і проведення навчальних занять в медичних вузах (метод. посібник) / В. С. Мілерян. - Київ : Хрещатик, 2003. - 80 с.

5. Педагогіка вищої школи : навч. посіб. / [3. Н. Курлянд, Р. І. Хмелюк, А. В. Семенова та ін.]; за ред. 3. Н. Курлянд. [3-тє вид., перероб. і доп.]. - К. : Знання, 2007. -495 с.

6. Якібчук М. В. Напрями розвитку гуманізації і комунікаційна компетентність у контексті безперервної освіти / М. В. Якібчук // Наук. часопис Національного педагогічного університету ім. М. П. Драгоманова. - Серія 7. Релігієзнавство. Культурологія. Філософія. - № 11 (21). - Київ, 2007. $-153 \mathrm{c}$. 